УДК 616-089.819-089.84-018.2-085:547.995.15

DOI 10.11603/2414-4533.2019.3.10471

(CI. К. МОРАР ${ }^{1}$, В. В. ВЛАСОВ ${ }^{2}$, В. Ю. БОДЯКАㄹ, К. А. ПОХОДУН

ВДНЗ України “Буковинський державний медичний університет”1

Хмельницька обласна лікарня²

Тернопільський національний медичний університет імені І. Я. Горбачевського МОЗ Україниз

\title{
Вплив гіалуронової кислоти на морфологічні особливості грануляційної тканини лапаротомної рани при використанні безперервного обвивного швва
}

\begin{abstract}
Мета роботи: вивчити в експерименті вплив місцевого застосування гіалуронової кислоти на морфологічні особливості грануляційної тканини лапаротомної рани при зашиванні останньої безперервним обвивним швом.

Матеріали і методи. Проведено експеримент на 108 лабораторних щурах, яким виконано серединну лапаротомію та зведено краї м’язово-апоневротичного шару передньої черевної стінки безперервним обвивним швом. Тваринам основної групи на лінію шва м’язово-апоневротичного шару наносили безбарвний прозорий в’язкий гель гіалуронової кислоти. Забір біологічного матеріалу проводили на 1-шу, 7-му та 14-ту доби після виконання оперативного втручання.

Результати досліджень та їх обговорення. Встановлено, що місцеве застосування гіалуронової кислоти при зашиванні країв м’язово-апоневротичного шару передньої черевної стінки за допомогою безперервного обвивного шва призводить до пригнічення дозрівання грануляційної тканини, оскільки спостерігається вірогідне зниження відсотка фібробластів, плазматичних клітин та зростання лімфоїдних клітин і нейтрофілів, а також питомого об’єму кровоносних судин на 14-ту добу спостереження.
\end{abstract}

Ключові слова: грануляційна тканина; лапаротомна рана; безперервний обвивний шов; гіалуронова кислота.

Постановка проблеми і аналіз останніх досліджень та публікацій. Основною причиною виникнення евентрацій та післяопераційних вентральних гриж завжди є морфофункціональна недостатність рубця передньої черевної стінки, внаслідок пригнічення репаративних властивостей тканин, що має місце при гіпопротеїнемії, анемії, гіповітамінозі, цукровому діабеті, раковій кахексії тощо [2 - 4].

Пошук нових методів раціональної фармакологічної патогенетичної терапії спрямованої на прискорення процесів репарації післяопераційних ран $є$ актуальною проблемою хірургії [5 - 8].

Останнім часом з'являється все більше наукових робіт, де вивчено роль гіалуронової кислоти у прискоренні процесів загоєння ран, проте залишається невідомим, як остання впливає на морфологію грануляційної тканини лапаротомної рани при використанні безперервного обвивного шва.

Мета роботи: вивчити в експерименті вплив місцевого застосування гіалуронової кислоти на морфологічні особливості грануляційної тканини лапаротомної рани при зашиванні останньої безперервним обвивним швом.

Матеріали і методи. Експеримент виконано на 108 статевозрілих нелінійних щурах середнього віку обох статей, масою не менше 180 г, яким виконано серединну лапаротомію завдовжки до 3,0 см та зведено краї м'язово-апоневротичного шару передньої черевної стінки безперервним обвивним швом.
Тваринам основної групи перед зашиванням шкіри на лінію шва м'язово-апоневротичного шару передньої черевної стінки наносили безбарвний прозорий в'язкий гель гіалуронової кислоти. У якості гіалуронової кислоти використовували препарат ЛАЦЕРТА 1,5 \% фірми “Юрія-Фарм”.

Використовували шовний матеріал Вікрил, розмірами USP 4/0, колючою голкою 20 мм, 1/2 круга, довжиною 75 см.

Забір біологічного матеріалу проводили на 1-шу, 7-му та 14-ту доби після виконання оперативного втручання, шляхом висічення м'язовоапоневротичного шару передньої черевної стінки разом із шкірою, під загальним в/м знеболенням (розчин хлоралгідрату 200-250 мг/кг) 3 дотриманням правил асептики.

Хірургічні втручання виконано в умовах віварію ВДНЗ України “Буковинський державний медичний університет”, відповідно до національних вимог "Загальних етичних принципів експериментів на тваринах” (Україна, 2011), які узгоджені з положенням “Європейської конвенції про захист хребетних тварин, що використовуються для експериментів та інших наукових цілей” (Страсбург, 1985).

Евтаназію щурів здійснювали згідно з етичними стандартами та діючими рекомендаціями, у стані глибокого наркозу, шляхом уведення надлишкової кількості наркотичного препарату, згідно із законом України № 3447-1 від 21.02.2006 р. “Про захист тварин від жорстокого поводження”. 
Для світлооптичного дослідження, при гістологічному дослідженні, біоптати м'язово-апоневротичного шару передньої черевної стінки фіксували в $10 \%$ нейтральному формаліні. Парафінові зрізи забарвлювали гематоксиліном та еозином, а для ідентифікації колагенових волокон та фібрину використовували методику забарвлення гістологічних зрізів водним блакитним - хромотропом 2 В за Н. 3. Слінченко [1]. Використовували описову методику виявлених патоморфологічних змін.

Для цілей морфометрії за допомогою комп’ютерної мікроденситометрії (комп'ютерна програмa ImageJ 1.48 v) проводили визначення оптичної густини забарвлених колагенових волокон водним блакитним (в. од. опт. густини), питомий об'єм колагенових волокон на одиницю площі грануляційної тканини (\%), питомий об'єм кровоносних судин в грануляційній тканині (\%).

Статистичний аналіз отриманих результатів проводили з використанням електронних таблиць Microsoft Excel та пакета програм статистичної обробки PAST. Для перевірки нормальності розподілу даних у вибірках застосовували критеpiï Shapiro-Wilk. Розбіжності між групами досліджень визначали за допомогою критеріїв MannWhithey. Результат вважали вірогідним, якщо коефіцієнт вірогідності був $\leq 0,05$, що є загальноприйнятим у медико-біологічних дослідженнях.

Результати досліджень та їх обговорення. Аналіз результатів дослідження, представлений в таблиці 1 , показує вірогідне переважання відсотка фібробластів у грануляційній тканині тварин основній групи на 1-шу добу спостереження. Починаючи з 7-ї доби дослідження вірогідно переважає відсоток фібробластів у грануляційній тканині тварин групи порівняння. Впродовж всього терміну спостереження в обох дослідних групах тварин у грануляційній тканині спостерігається вірогідне зростання відсотка фібробластів.

Наведені результати дослідження (табл. 2) вказують на переважання відсотка лімфоїдних клітин

Таблиця 1. Динаміка відсотка фрібробластів грануляційної тканини лапаротомної рани в різні терміни

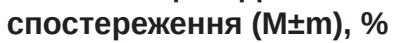

\begin{tabular}{||c|c|c||}
\hline \multirow{2}{*}{$\begin{array}{c}\text { Терміни спостереження, } \\
\text { доба }\end{array}$} & \multicolumn{2}{|c|}{ Група тварин } \\
\cline { 2 - 3 } & $\begin{array}{c}\text { порівняння } \\
\mathrm{n}=18\end{array}$ & $\begin{array}{c}\text { основна } \\
\mathrm{n}=22\end{array}$ \\
\hline 1 -ша & $0,5 \pm 0,07$ & $1,2 \pm 0,16$ \\
& & $\mathrm{p}<0,001$ \\
\hline 7 -ма & $57,1 \pm 0,85$ & $45,3 \pm 0,79$ \\
& $\mathrm{p}_{1}<0,001$ & $\mathrm{p}<0,001 ; \mathrm{p}_{1}<0,001$ \\
\hline $14-$ та & $91,5 \pm 0,96$ & $80,1 \pm 0,81$ \\
& $\mathrm{p}_{1}<0,001^{*}$ & $\mathrm{p}<0,001 ; \mathrm{p}_{1}<0,001 *$ \\
\hline
\end{tabular}

Примітки. Тут і в таблицях 2-8:

1) n - кількість спостережень;

2) р - різниця між обома дослідними групами;

3) $\mathrm{p}_{1}$ - різниця проти показників 1-ї доби спостереження;

4) * - вірогідна різниця проти показників 7-ї доби.

Таблиця 2. Динаміка відсотка лімфоїдних клітини грануляційної тканини лапаротомної рани в різні

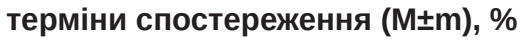

\begin{tabular}{||c|c|c||}
\hline \multirow{2}{*}{$\begin{array}{c}\text { Терміни спостереження, } \\
\text { доба }\end{array}$} & \multicolumn{2}{|c|}{ Група тварин } \\
\cline { 2 - 3 } & $\begin{array}{c}\text { порівняння } \\
\mathrm{n}=18\end{array}$ & $\begin{array}{c}\text { основна } \\
\mathrm{n}=22\end{array}$ \\
\hline 1 -ша & $43,6 \pm 0,67$ & $44,1 \pm 0,61$ \\
& & $\mathrm{p}>0,05$ \\
\hline 7-ма & $27,5 \pm 0,71$ & $41,3 \pm 0,63$ \\
& $\mathrm{p}_{1}<0,001$ & $\mathrm{p}<0,001 ; \mathrm{p}_{1}<0,01$ \\
\hline 14 -та & $3,9 \pm 0,38$ & $15,8 \pm 0,49$ \\
& $\mathrm{p}_{1}<0,001 *$ & $\mathrm{p}<0,001 ; \mathrm{p}_{1}<0,001 *$ \\
\hline
\end{tabular}


у грануляційній тканині в тварин основної групи, за винятком того, що різниця показників 1-ї доби спостереження не вірогідна. В обох дослідних групах тварин впродовж всього терміну спостереження спостерігається вірогідне зниження відсотка лімфоїдних клітин у грануляційній тканині.

Оцінюючи результати дослідження відсотка макрофагів грануляційної тканини, які представлені в таблиці 3, слід вказати на вірогідну різницю показників між обома дослідними групами тварин. У тварин основної групи, на відміну від порівняння, на 14-ту добу спостереження спостерігається вірогідно менший відсоток макрофагів, проти 1-ї доби дослідження.

Аналіз результатів (табл. 4), підтверджує вірогідне переважання відсотка плазматичних клітин у грануляційній тканині тварин групи порівняння впродовж перших 7-ми діб спостереження, оскільки на 14-ту добу в обох дослідних групах мають місце поодинокі клітини. У тварин групи порівняння, на відміну від основної, спостерігається вірогідне зниження відсотка плазматичних клітин у грануляційній тканині проти 1-ї доби дослідження.

Результати дослідження представлено в таблиці 5 вказують на вірогідно вищий відсоток нейтрофілів у грануляційній тканині тварин основної групи. На 14-ту добу спостереження спостерігаються поодинокі нейтрофіли в грануляційній тканині тварин обох дослідних груп. Відсоток нейтрофілів в грануляційній тканині на 7-му добу дослідження у тварин обох дослідних груп вірогідно нижчий проти 1-ї доби спостереження.

Отже, місцеве застосування гіалуронової кислоти при зведенні країв лапаротомної рани за до-

Таблиця 3. Динаміка відсотка макрофагів грануляційної тканини лапаротомної рани в різні терміни спостереження (M $\pm \mathrm{m}), \%$

\begin{tabular}{|c|c|c||}
\hline \multirow{2}{*}{$\begin{array}{c}\text { Терміни спостереження, } \\
\text { доба }\end{array}$} & \multicolumn{2}{|c|}{ Група тварин } \\
\cline { 2 - 3 } & $\begin{array}{c}\text { порівняння } \\
\mathrm{n}=18\end{array}$ & $\begin{array}{c}\text { основна } \\
\mathrm{n}=22\end{array}$ \\
\hline 1-ша & $5,3 \pm 0,42$ & $6,2 \pm 0,47$ \\
& & $\mathrm{p}>0,05$ \\
\hline 7-ма & $10,6 \pm 0,51$ & $9,2 \pm 0,48$ \\
& $\mathrm{p}_{1}<0,001$ & $\mathrm{p}>0,05 ; \mathrm{p}_{1}<0,001$ \\
\hline $14-$ та & $4,1 \pm 0,42$ & $4,1 \pm 0,31$ \\
& $\mathrm{p}_{1}>0,05 *$ & $\mathrm{p}>0,05 ; \mathrm{p}_{1}<0,01 *$ \\
\hline
\end{tabular}

Таблиця 4. Динаміка відсотка плазматичних клітини грануляційної тканини лапаротомної рани в різні

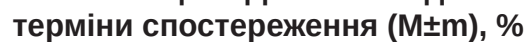

\begin{tabular}{|c|c|c||}
\hline \multirow{2}{*}{$\begin{array}{c}\text { Терміни спостереження, } \\
\text { доба }\end{array}$} & \multicolumn{2}{|c|}{ Група тварин } \\
\cline { 2 - 3 } & $\begin{array}{c}\text { порівняння } \\
\mathrm{n}=18\end{array}$ & $\begin{array}{c}\text { основна } \\
\mathrm{n}=22\end{array}$ \\
\hline 1 -ша & $8,5 \pm 0,42$ & $2,1 \pm 0,19$ \\
& & $\mathrm{p}<0,001$ \\
\hline 7-ма & $4,3 \pm 0,35$ & $2,1 \pm 0,24$ \\
& $\mathrm{p}_{1}<0,001$ & $\mathrm{p}<0,001 ; \mathrm{p}_{1}>0,05$ \\
\hline
\end{tabular}

Таблиця 5. Динаміка відсотка нейтрофрілів грануляційної тканини лапаротомної рани в різні терміни

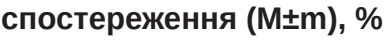

\begin{tabular}{||c|c|c||}
\hline \hline \multirow{2}{*}{$\begin{array}{c}\text { Терміни спостереження, } \\
\text { доба }\end{array}$} & \multicolumn{2}{|c||}{ Група тварин } \\
\cline { 2 - 3 } & $\begin{array}{c}\text { порівняння } \\
\mathrm{n}=18\end{array}$ & $\begin{array}{c}\text { основна } \\
\mathrm{n}=22\end{array}$ \\
\hline 1 -ша & $42,1 \pm 0,73$ & $46,4 \pm 0,71$ \\
& & $\mathrm{p}<0,001$ \\
\hline 7-ма & $0,5 \pm 0,07$ & $2,1 \pm 0,26$ \\
& $\mathrm{p}_{1}<0,001$ & $\mathrm{p}<0,001 ; \mathrm{p}_{1}<0,001$ \\
\hline
\end{tabular}


помогою безперервного обвивного шва призводить до вірогідного зниження відсотка фібробластів, плазматичних клітин у грануляційній тканині, а також зростання лімфоїдних клітин та нейтрофілів (рис. 1, 2, 4, 6).

При забарвлені мікропрепаратів водним блакитним - хромотропом 2В, на 1-шу добу після виконання операції, в обох дослідних групах тварин, спостерігається виражений набряк тканин та фібрин у вигляді сітки (рис. 3).

Результати дослідження, представлено в таблиці 6, свідчать, що на 7-му добу спостереження

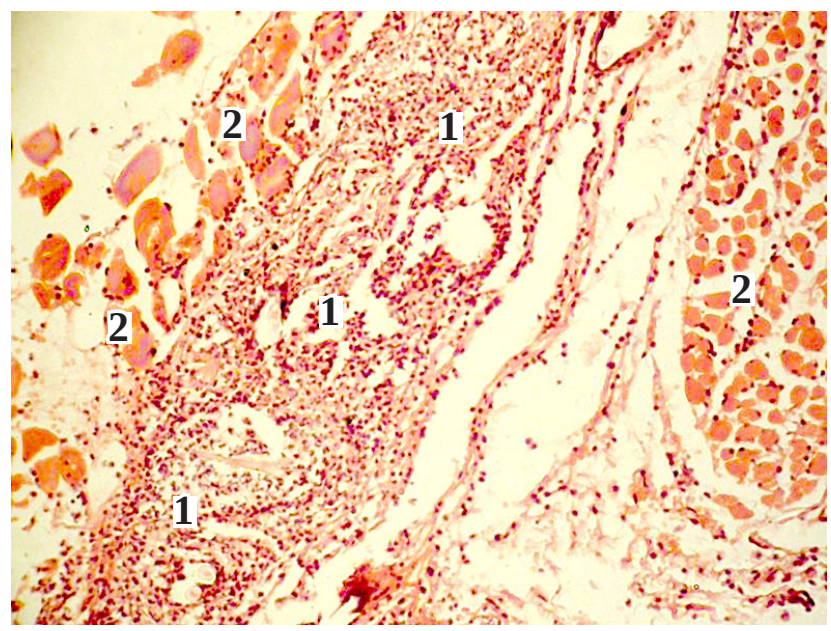

Рис. 1. Фото мікропрепарату передньої черевної стінки щура на 1-шу добу після зашивання лапаротомної рани безперервним обвивним швом (група порівняння). Грануляційна тканина (1). Кровоносні судини (2). Гематоксилін і еозин. Об. $10^{\times}$. Ок. $10^{\times}$.

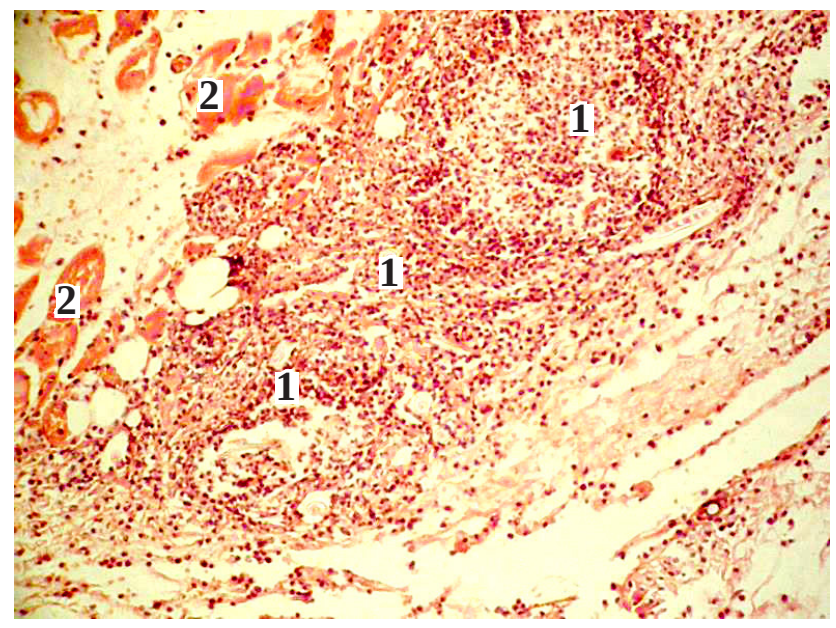

Рис. 2. Фото мікропрепарату передньої черевної стінки щура на 1-шу добу після зашивання лапаротомної рани безперервним обвивним швом (основна група). Грануляційна тканина (1). М'язи передньої черевної стінки (2). Гематоксилін і еозин. Об. $10^{\times}$. Ок. $10^{\times}$. спостерігається вірогідне переважання питомого об’єму колагенових волокон на одиницю площі грануляційної тканини тварин основної групи, проте на 14-ту добу різниця показників між обома дослідними групами невірогідна. В обох дослідних групах впродовж всього терміну спостереження спостерігається вірогідне зростання питомого об’єму колагенових волокон у грануляційній тканині (рис. 5, 7).

Наведені в таблиці 7 результати дослідження оптичної густини забарвлених колагенових волокон грануляційної тканини вказують на вірогідне переважання показників у тварин основної групи на 7-му

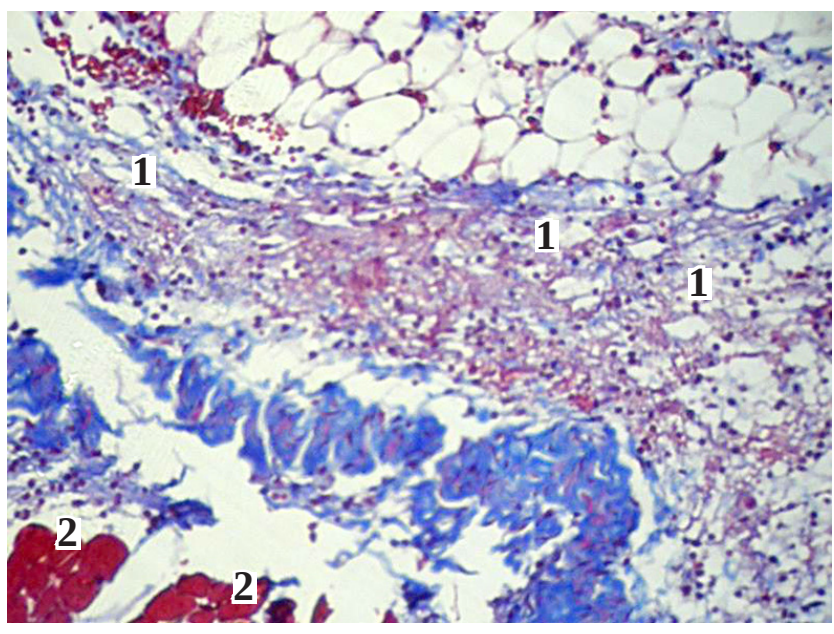

Рис. 3. Фото мікропрепарату передньої черевної стінки щура на 1-шу добу після зашивання лапаротомної рани безперервним обвивним швом (основна група). Колагенові волокна (1). М'язи передньої черевної стінки (2). Забарвлення водним блакитним-хромотропом 2В. Об. $10^{\times}$. Ок. $10^{\times}$.

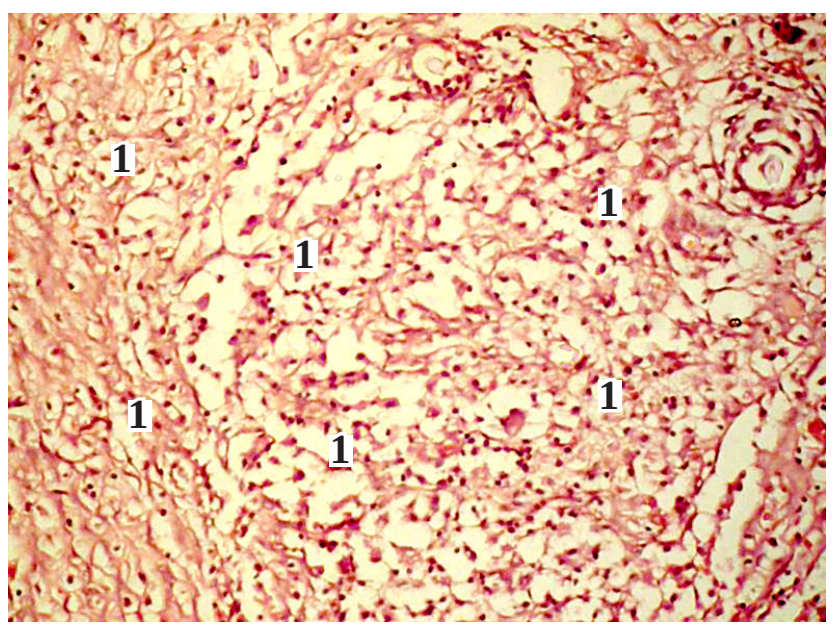

Рис. 4. Фото мікропрепарату передньої черевної стінки щура на 14-ту добу після зашивання лапаротомної рани безперервним обвивним швом (група порівняння). Грануляційна тканина (1). Гематоксилін і еозин. Об. $10^{\times}$. Ок. $10^{\times}$. 


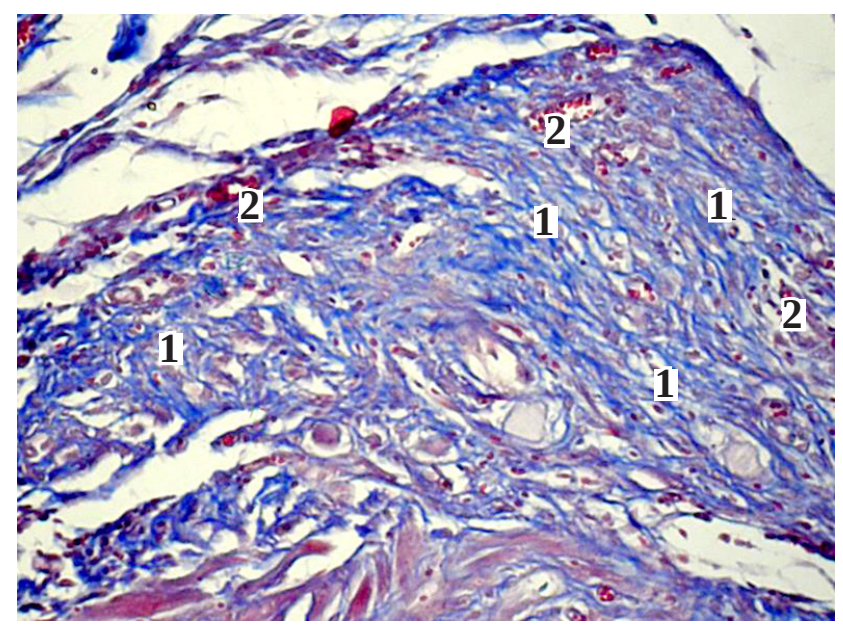

Рис. 5. Фото мікропрепарату передньої черевної стінки щура на 14-ту добу після зашивання лапаротомної рани безперервним обвивним швом (група порівняння). Колагенові волокна (1). Кровоносні судини (2). Забарвлення водним блакитним-хромотропом 2В. Об. $10^{\times}$. Ок. $10^{\times}$.

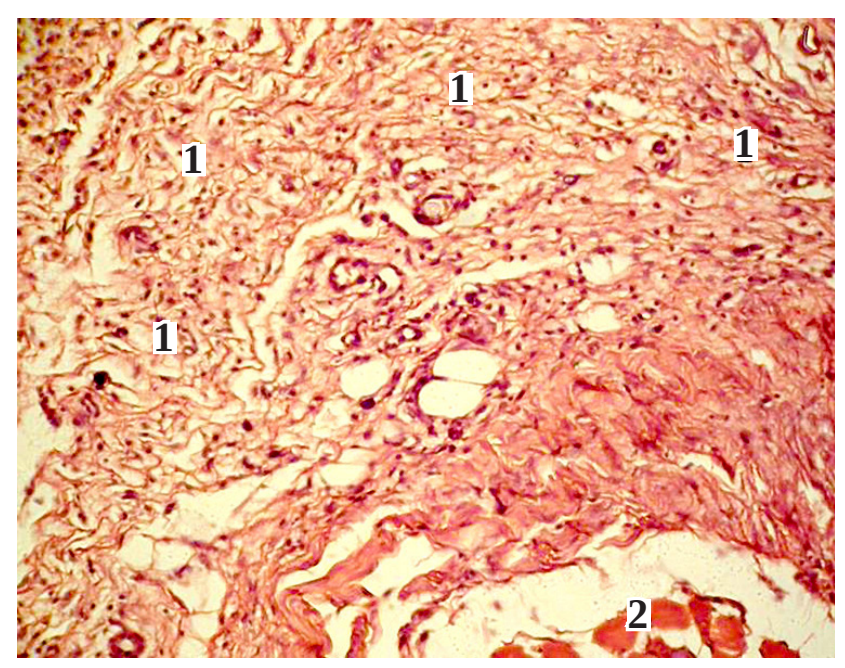

Рис. 6. Фото мікропрепарату передньої черевної стінки щура на 14-ту добу після зашивання лапаротомної рани безперервним обвивним швом (основна група). Грануляційна тканина (1). М'язи передньої черевної стінки (2). Гематоксилін і еозин. Об. $10^{\times}$. Ок. $10^{\times}$.

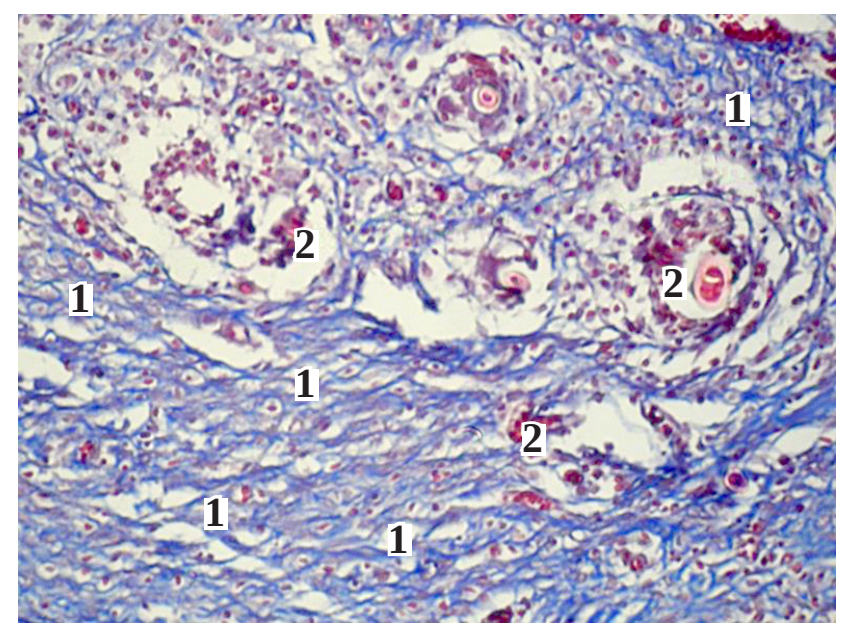

Рис. 7. Фото мікропрепарату передньої черевної стінки щура на 14-ту добу після зашивання лапаротомної рани безперервним обвивним швом (основна група). Колагенові волокна (1). Кровоносні судини (2). Забарвлення водним блакитним-хромотропом 2В. Об. $10^{\times}$. Ок. $10^{\times}$.

добу спостереження, проте на 14-ту добу ця різниця невірогідна. Впродовж всього терміну дослідження, в обох дослідних групах тварин, спостерігається вірогідне зростання оптичної густини забарвлених колагенових волокон у грануляційній тканині.

Результати дослідження, представлені в таблиці 8, вказують на вірогідне переважання питомого об'єму кровоносних судин у грануляційній тканині тварин групи порівняння на 1-шу та 7-му доби спостереження, проте на 14-ту - навпаки, переважають показники тварин основної групи. У тварин основної групи, на відміну від порівняння, спостерігається зростання питомого об'єму кровоносних судин у грануляційній тканині, проти 1-ї доби спостереження, проте ця динаміка невірогідна.

Таким чином, морфологічна картина грануляційної тканини лапаротомної рани при застосуванні гіалуронової кислоти відрізняється вірогідними переважанням питомого об'єму кровоносних судин на 14-ту добу спостереження.

Таблиця 6. Динаміка питомого об'єму колагенових волокон на одиницю площі грануляційної тканини лапаротомної рани в різні терміни спостереження, \%

\begin{tabular}{||c|c|c||}
\hline \hline \multirow{2}{*}{$\begin{array}{c}\text { Терміни спостереження, } \\
\text { доба }\end{array}$} & \multicolumn{2}{|c|}{ Група тварин } \\
\cline { 2 - 3 } & порівняння & основна \\
$\mathrm{n}=18$ & $38,3 \pm 0,61$ & $42,3 \pm 0,72$ \\
$\mathrm{7}$-ма & & $\mathrm{p}<0,001$ \\
\hline & $54,4 \pm 0,83$ & $52,2 \pm 0,85$ \\
& $\mathrm{p}_{1}<0,001$ & $\mathrm{p}>0,05 ; \mathrm{p}_{1}<0,001$ \\
\hline
\end{tabular}


Таблиця 7. Динаміка оптичної густини забарвлених колагенових волокон водним блакитним грануляційної тканини лапаротомної рани в різні терміни спостереження у відносних одиницях оптичної густини

\begin{tabular}{||c|c|c||}
\hline \multirow{2}{*}{$\begin{array}{c}\text { Терміни спостереження, } \\
\text { доба }\end{array}$} & \multicolumn{2}{|c||}{ Група тварин } \\
\cline { 2 - 3 } & $\begin{array}{c}\text { порівняння } \\
\mathrm{n}=18\end{array}$ & $\begin{array}{c}\text { основна } \\
\mathrm{n}=22\end{array}$ \\
\hline 7-ма & $0,186 \pm 0,0026$ & $0,142 \pm 0,0016$ \\
& & $\mathrm{p}<0,001$ \\
\hline 14 -та & $0,224 \pm 0,0030$ & $0,232 \pm 0,0026$ \\
& $\mathrm{p}_{1}<0,001$ & $\mathrm{p}>0,05 ; \mathrm{p}_{1}<0,01$ \\
\hline
\end{tabular}

Таблиця 8. Динаміка питомого об'єму кровоносних судин у грануляційній тканині лапаротомної рани в різні терміни спостереження, \%

\begin{tabular}{||c|c|c||}
\hline \multirow{2}{*}{$\begin{array}{c}\text { Терміни спостереження, } \\
\text { доба }\end{array}$} & \multicolumn{2}{|c||}{ Група тварин } \\
\cline { 2 - 3 } & порівняння & основна \\
$\mathrm{n}=18$ & $\mathrm{n}=22$ \\
\hline 1 -ша & $6,4 \pm 0,54$ & $3,1 \pm 0,27$ \\
& & $\mathrm{p}<0,001$ \\
\hline 7 -ма & $15,2 \pm 0,63$ & $8,2 \pm 0,37$ \\
& $\mathrm{p}_{1}<0,001$ & $\mathrm{p}<0,001 ; \mathrm{p}_{1}<0,001$ \\
\hline 14 -та & $2,3 \pm 0,25$ & $4,1 \pm 0,48$ \\
& $\mathrm{p}_{1}<0,001^{*}$ & $\mathrm{p}<0,01 ; \mathrm{p}_{1}>0,05^{*}$ \\
\hline
\end{tabular}

Отже, отримані результати дослідження вказують, що місцеве застосування гіалуронової кислоти при зашиванні країв м’язово-апоневротичного шару передньої черевної стінки за допомогою безперервного обвивного шва, призводить до пригнічення дозрівання грануляційної тканини.

Висновки. Місцеве застосування гіалуронової кислоти при зашиванні країв м’язово-апонев- ротичного шару передньої черевної стінки, за допомогою безперервного обвивного шва, призводить до вірогідного зниження відсотка фібробластів, плазматичних клітин у грануляційній тканині та зростання лімфоїдних клітин, нейтрофілів, а також питомого об’єму кровоносних судин на 14-ту добу спостереження, що свідчить про зміни в репаративних процесах у рані.

\section{СПИСОК ЛІТЕРАТУРИ}

1. Коржевский Д. Э. Основы гистологической техники / Д. Э. Коржевский, А. В. Гиляров. - Санкт-Петербург : СпецЛит, 2010. - С. 96.

2. Anate M. Skin closure of laparotomy wounds: absorbable subcuticular sutures vs. non-absorbable interrupted sutures / M. Anate // West Afr. J. Med. - 1991. - Vol. 10 (2). - P. 150-157. 3. Study of two techniques for midline laparotomy fascial wound closure / V. Gurjar, B. M. Halvadia, R. P. Bharaney, [et al.] // Indian J. Surg. - 2014. - Vol. 76 (2). - P. 91-94.

4. Israelsson L. A. Suture technique and wound healing in midline laparotomy incisions / L. A. Israelsson, T. Jonsson, A. Knutsson // Eur. J. Surg. - 1996. - Vol. 162 (8). - P. 605-609.

5. The Donati stitch revisited: favorable cosmetic results in a

randomized clinical trial / J. B. Trimbos, R. Mouw, G. Ranke [et al.] // J. Surg. Res. - 2002. - Vol. 107 (1). - P. 131-134.

6. Kuchumov V. A. Differentiated application of single-row suture for prevention of surgical infection in abdominal surgery / V. A. Samartsev, V. A. Gavrilov, A. G. Kuchumov // Novosti Khirurgii. - 2013. - Vol. 21 (6). - P. 38-46.

7. Соколова М. А. Роль гиалуроновой кислоты в организме человека / М. А. Соколова // Мезотерапия. - 2009. - № 8. - C. 6-12.

8. Торотадзе Н. Н. Экспериментальные данные о заживлении раны брюшной стенки после релапаротомии, ушитой синтетическими швами / Н. Н. Торотадзе // Таврический медико-биологический вестник. - 2010. - Т. 13, № 3 (51). - С. 193-195. 


\section{REFERENCES}

1. Korzhevskyy, D.E., \& Gilyarov, A.B. (2010). Osnovy gistologicheskoy tekhniki [Fundamentals of histological technique]. St. Petersburg [in Russian].

2. Anate, M. (1991). Skin closure of laparotomy wounds: absorbable subcuticular sutures vs. non-absorbable interrupted sutures. West Afr. J. Med., 10 (2), 150-157.

3. Gurjar, V., Halvadia, B.M., \& Bharaney, R.P. (2014). Study of two techniques for midline laparotomy fascial wound closure. Indian J. Surg., 76 (2), 91-94.

4. Israelsson, L.A., Jonsson, T., \& Knutsson, A. (1996). Suture technique and wound healing in midline laparotomy incisions. Eur. J. Surg., 162 (8), 605-609.

5. Trimbos, J.B., Mouw, R., Ranke, G. (2002). The Donati stitch revisited: favorable cosmetic results in a randomized clinical trial.
J. Surg. Res., 107 (1), 131-134.

6. Samartsev, V.A., Gavrilov, V.A., \& Kuchumov, A.G. (2013). Differentiated application of single-row suture for prevention of surgical infection in abdominal surgery. Novosti Khirurgii, 21 (6), 3846.

7. Sokolova, M.A. (2009). Rol gialuronovoy kisloty v organizme cheloveka [The role of hyaluronic acid in the human body]. Mezoterapiya-Mesotherapy, 8, 6-12 [in Russian].

8. Torotadze, N.N. (2010). Eksperimentalnye dannye o zazhivlenii rany bryushnoy stenki posle relaparotomii, ushitoy sinteticheskimi shvami [Experimental data on the healing of wounds of the abdominal wall after relaparotomy sutured with synthetic sutures]. Tavricheskiy mediko-biologicheskiy vestnik - Tavricheskiy Medical and Biological Bulletin, 13, 3 (51), 193-195 [in Russian].

Отримано 20.08.2019

Електронна адреса для листування: igor.morar82@gmail.com

\title{
I. K. MORAR ${ }^{1}$, V. V. VLASOV², V. YU. BODYAKA ${ }^{1}$, K. A. POKHODUN ${ }^{3}$, Y. U. CHUPROVSKAYA
}

Bukovinian State Medical University ${ }^{1}$

Khmelnytskyi Regional Hospital²

I. Horbachevsky Ternopil National Medical University ${ }^{3}$

\section{THE INFLUENCE OF HYALURONIC ACID ON THE MORPHOLOGICAL PECULIARITIES OF THE GRANULATION TISSUE OF THE LAPAROTOMIC WOUND IN USING A CONTINUOUS LOCKING STITCH}

\begin{abstract}
The aim of the work: to investigate in the experiment the effect of topical application of hyaluronic acid on the morphological features of the granulation tissue of the laparotomy wound when suturing the last with continuous locking stitch.

Materials and Methods. An experiment was performed on 108 laboratory rats, which underwent a median laparotomy and reduced the edges of the musculoaponeurotic layer of the anterior abdominal wall with a continuous locking stitch. The animals of the main group were treated with a colorless transparent viscous hyaluronic acid gel on the suture line of the musculoaponeurotic layer. A sampling of biological material was performed on the 1st, 7th and 14th days after surgery.

Results and Discussion. It has been established that topical application of hyaluronic acid in the suturing of the edges of the musculoaponeurotic layer of the anterior abdominal wall by means of a continuous locking stitch leads to inhibition of the maturation of granulation tissue, since a marked decrease in the percentage of fibroblasts, plasmacytic cells and volume of blood vessels on the 14th day of observation.
\end{abstract}

Key words: granulation tissue; laparotomy wound; continuous locking stitch; hyaluronic acid.

\section{И. К. МОРАР ${ }^{1}$, В. В. ВЛАСОВ ${ }^{2}$ В. Ю. БОДЯКА}

ВГУЗ Украины “Буковинский государственный медицинский университет”1

Хмельницкая областная больница ${ }^{2}$

Тернопольский национальный медицинский университет имени И. Я. Горбачевского МОз Украины ${ }^{3}$

\section{В.ЛИЯНИЕ ГИАЛУРОНОВОЙ КИС.ЛОТЫ НА МОРФОЛОГИЧЕСКИЕ ОСОБЕННОСТИ ГРАНУЛЯЦИОННОЙ ТКАНИ.ЛАПАРОТОМНОЙ РАНЫ ПРИ ИСПО.ЛЬЗОВНИИ НЕПРЕРЫВНОГО ОБВИВНОГО ІІІВА}

\begin{abstract}
Цель работы: изучить в эксперименте влияние местного использования гиалуроновой кислоты на морфологические особенности грануляционной ткани лапаротомной раны при сшивании последней непрерывным обивным швом.

Материалы и методы. Проведено эксперимент на 108 лабораторных крысах, которым выполнено срединную лапаротомию и сопоставлено края мышечно-апоневротического слоя передней брюшной стенки непрерывным обивным швом. Животным основной группы на линию шва мышечно-апоневротического слоя наносили прозрачный вязкий гель гиалуроновой кислоты. Забор биологического материалу проводили на 1-ю, 7-ю и 14-ю сутки после выполнения оперативного вмешательства.

Результаты исследований и их обсуждения. Определено, что местное использование гиалуроновой кислоты при сшивании краев мышечно-апоневротического слоя с помощью непрерывного обивного шва приводит к угнетению дозревания грануляционной ткани, поскольку отмечается достоверное снижение процента фибробластов, плазматических клеток и увеличение лимфоидных клеток и нейтрофилов, а также удельного объема кровеносных сосудов на 14-е сутки наблюдения.
\end{abstract}

Ключевые слова: грануляционная ткань; лапаротомная рана; непрерывный обвивной шов; гиалуроновая кислота. 